\title{
Allelopathic potential of Gleichenella pectinata (Willd.) Ching on weed plant species
}

Valquiria Marin Voltarelli ${ }^{1}$, Jose Pedro Nepomuceno Ribeiro ${ }^{1,2}$ and Maria Inês Salgueiro Lima ${ }^{1}$

Recebido em 18/05/2011. Aceito em 20/06/2012

\begin{abstract}
RESUMO
(Potencial alelopático de Gleichenella pectinata (Willd.) Ching (Gleicheniaceae) sobre espécies infestantes de culturas). Com o objetivo de determinar o potencial alelopático de Gleichenella pectinata sobre três espécies de plantas infestantes de culturas (Echinochloa crus-galli (L.) Beauv (Poaceae), Ipomoea grandifolia (Dammer) O'Donell (Convolvulaceae) e Euphorbia heterophylla L. (Euphorbiaceae)) foram realizados experimentos em laboratório. O delineamento experimental foi totalmente casualizado, com seis tratamentos e cinco réplicas. As respostas das plantas alvo foram analisadas individualmente (porcentagem e tempo de germinação das sementes e crescimento inicial das plântulas) ou combinadas, através do Índice do efeito Global. Os extratos tiveram pouco efeito sobre a porcentagem e tempo de germinação das sementes, mas inibiram significativamente o tamanho das plântulas. A análise combinada dos parâmetros revelou uma inibição provocada por quase todos os tratamentos. Essa análise evidenciou também efeitos distintos entre os extratos de frondes férteis e frondes estéreis.
\end{abstract}

Palavras chave: Alelopatia, estado fenológico, extratos aquosos, Gleicheniaceae, Pteridófita

\begin{abstract}
(Allelopathic potential of Gleichenella pectinata (Willd.) Ching (Gleicheniaceae) on weed species). The goal of this paper was to determine the allelopathic potential of Gleichenella pectinata on three weed species (Echinochloa crus-galli (L.) Beauv (Poaceae), Ipomoea grandifolia (Dammer) O 'Donell (Convolvulaceae) and Euphorbia heterophylla L. (Euphorbiaceae)). The experimental design was entirely randomized, with six replicates. The target plant responses were analyzed individually (percentage and average time of germination of the seeds and initial growth of seedlings) or combined, using the Global Effect Index. The extracts had a low effect on the percentage and average time of seed germination, but inhibited the seedling growth. The combined analysis revealed that almost all treatments caused inhibition. This analysis also showed the differences between the two phenological stages.
\end{abstract}

Key words: Allelopathy, phenological stage, Gleicheniaceae, Pteridophyta, aqueous extracts

\section{Introduction}

Weed plants represent one of the main problems of global agriculture. They decrease productivity and are a setback for the management and harvest of the given culture, which leads to an annual loss of approximately U $\$ 95$ billion (FAO 2009). The current principal way of controlling weed plants relies on synthetic herbicides (Hong et al. 2004), and in Brazil the cost of using these products was in excess of 4,6 billion in 2008 (SINDAG 2008).

Nevertheless, the growth in weed resistance to herbicides is occurring as a global phenomenon, which is characterized by the decrease of response of populations to chemical products at recommended dosages (Gelmini, et al. 2001). Emergence of plants with resistant characteristics results from a dynamic evolutionary process in which these biotypes, resistant to a determined product, are positively selected due to an intensive use of herbicides (Christoffoleti et al. 1994; Tranel and Wright 2002).

The possibility of combating weed plants using allelochemicals is widely recognized (Rice 1984; Durán-Serantes et al. 2002; Ribeiro et al. 2009; Matsumoto et al. 2010). These secondary metabolism products possess several advantages over traditional herbicides, such as their biodegradability,

\footnotetext{
${ }^{1}$ Universidade Federal de São Carlos, Programa de Pós Graduação em Ecologia e Recursos Naturais, São Carlos, SP, Brazil

${ }^{2}$ Author for correspondence: jpnr@alelopatia.com.br
} 
water solubility, and shorter half-life. Besides this, allelochemicals have a less specific action mechanism, so they are less likely to select resistant biotypes (Reigosa et al. 2001; Durán-Serantes et al. 2002).

Some Pteridophyta species have shown a powerful dominance within the areas they grow in. Frequently, the dominance of one species is related to strong allelopathic potential, and studies regarding allelopathic proprieties of the Gleicheniaceae have described plants in this group as strong donors of phytotoxic and inhibitory compounds (Peres et al. 1998; Soares and Vieira 2000). Populations of Gleichenia have shown the existence of several phytotoxins that are able to interfere with the germination and early development of certain plant species (Peres et al. 2004). Few reports have compared the different physiological stages of adult fronds of Gleicheniaceae as donor sources of allelochemicals (Moraes and Garcia 2007) and to the best of our knowledge weed plants have never been used as target species to evaluate the allelopathic potential of Pteridophyta.

The present study aimed to test and compare the allelopathic potential of aqueous extracts of sterile and fertile green fronds of Gleichenia pectinata on the germination and early development of the following weed plant species: Echinochloa crus-galli, Euphorbia heterophylla and Ipomoea grandifolia. We expected that, like other species of the family, G. pectinata possesses allelopathic properties, and that its extracts are capable of inhibiting the target species.

\section{Material and methods}

Three distinct spots on the bank of the Massaguaçu River were selected and individuals were collected from each of these locations, near the Caraguatatuba township $\left(23^{\circ} 37^{\prime} 20^{\prime \prime} \mathrm{S}\right.$, $45^{\circ} 21^{\prime} 25^{\prime \prime} \mathrm{W}$ ), São Paulo, Brazil. The collections were made in March of 2009 and botanical material was archived at the Universidade Federal de São Carlos Herbarium (HUFSCar), as identification numbers 7504 and 7505 . Fronds had their leaflets separated according to phenological stage (fertile or sterile) and were placed in an incubator at $40{ }^{\circ} \mathrm{C}$ up to mass stabilization. Afterwards, these materials were crushed in a mechanical mill and frozen until used. Fertile leaflets (with sporangia) were submitted to the same process. The extracts were prepared by mixing the botanical material with distilled water at a proportion of 1:9 weight/volume. The mixtures were refrigerated for 24 hours, and then filtered with a double layer of filter paper $\left(80 \mathrm{~g} . \mathrm{m}^{-2}, 205 \mu \mathrm{m}\right)$, resulting in crude extracts of the fertile (FF) and sterile (FS) fronds, both at $10 \%$ concentration. After filtering, dilutions of $2.5 \%$ and $5 \%$ were prepared. All of the extracts had their $\mathrm{pH}$ and osmotic potential measured. Gleichenia pectinata extracts were tested on seeds of Echinochloa crus-galli (L.) Beauv, Ipomoea grandifolia (Dammer) O'Donell (scarified according Azania et al. 2003) and Euphorbia heterophylla L.

The experiments were performed in two parts. First, Petri dishes $(9 \mathrm{~cm}$ diam.) were used to enclose 30 seeds of each weed species, which were subjected to the effects of $5 \mathrm{~mL}$ of the given concentration of the extract for the allelopathic treatments, or of $5 \mathrm{~mL}$ of distilled water for the control. Each dish was previously washed in distilled water, contained a double layer of filter paper $\left(80 \mathrm{~g} \mathrm{~m}^{-2}, 205 \mu \mathrm{m}\right.$.), and was sterilized in a microwave for 4 minutes under high power. Seeds were then placed on treatment, moistened filter paper in the dishes, which were sealed with cling film to avoid water loss. All of the Petri dishes were kept in BOD chambers at $28{ }^{\circ} \mathrm{C}( \pm 2)$ and a $12 \mathrm{~h}$. photoperiod. During the dark period, the Petri dishes were exposed to light while taking readings, every 12 hours up to the $192^{\text {nd }}$ hour. The number of germinated seeds were counted (rupture of seed coat with emergence of radicle equal or larger than $2 \mathrm{~mm}$ ) and those individuals were removed from the plates.

The second part of the experiment consisted of the analysis of allelopathic effects on early development of weed seedlings. Plastic transparent boxes $(8 \times 13 \times 5 \mathrm{~cm})$ were used, which were sterilized with $70 \%$ alcohol, and contained a double layer of filter paper previously sterilized in an autoclave, $12 \mathrm{~mL}$ of the given extract and ten seedlings (pre germinated in distilled water). The boxes were incubated in BOD chambers, at $28^{\circ} \mathrm{C}( \pm 2)$ and 12 -h. photoperiod, and after five days the growth was interrupted and measurements of the roots and aerial parts were taken. A qualitative analysis was also done using injuries and bad formation records.

An osmotic control was performed with a polietilenoglicol 6000 (PEG 6000) in order to verify the interference from the osmotic potential of the extracts (Villela et al. 1991). The results were compared to the controls. When no difference was found it was assumed that there was no interference on the results. When a difference occurred, the osmotic control data were compared to the results for that given osmolarity. An effect likely from osmotic potential of the extracts was considered when the control were equal or greater than the treatments.

In both phases controls were treated with distilled water. All controls and treatments were set with six replications. The measured parameters (percentage and average germination time of seeds) were analyzed individually, and combined using the Global Effect Index (Ribeiro 2011). In all cases, the significance among control and treatments was checked by the standard error x1.5.

\section{Results and discussion}

The $\mathrm{pH}$ values of the extracts were between 4.55 and 4.63, which is insufficient to inhibit germination of seeds and the early development of seedlings of the target species. (Souza Filho et al. 1996). Thus, the influence of the extracts' $\mathrm{pH}$ on the obtained results was considered insignificant. The osmotic potential varied from -0.23 up to $-0.28 \mathrm{MPa}$. The only two treatments for which the osmotic control exhibited the same interference were $10 \% \mathrm{FF}$ and SF tested on I. grandifolia. These treatments were removed from the 
analysis and all the other treatment results were considered due to the chemical characteristics of the extracts.

In general, the percentage and the average time of germination of seeds of the target species were slightly sensitive to the extracts. Only the $10 \%$ concentrated extracts achieved significant inhibition for all the species (figures 1 and 2). Ho- wever, early development was affected by all the treatments, except $2.5 \%$, SF attested by significant inhibition (figure 1C).

After applying the General Effect Index, the response of each species to the extracts was grouped in a single value. This union revealed some alterations provoked by treatments that had not been detected by the individual parameter analysis.

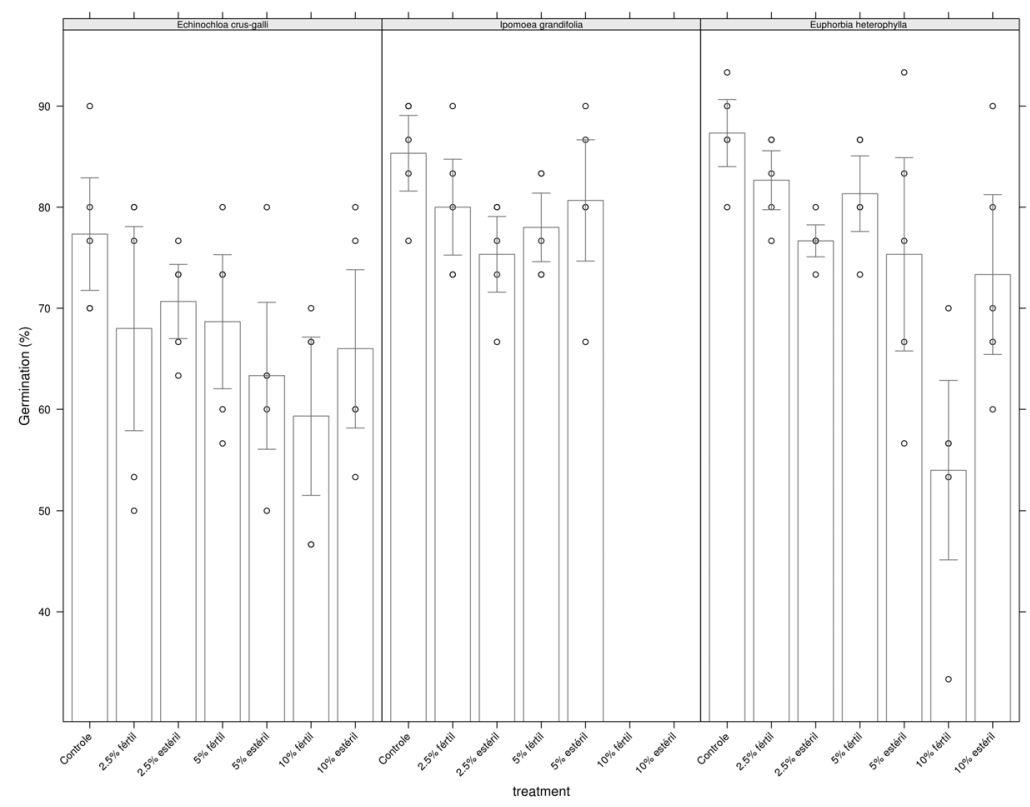

Figure 1. Germination percentage of seeds of Echinochloa crus-galli (L.) Beauv, Ipomoea grandifolia (Dammer) O'Donell and Euphorbia heterophylla L. submitted to the aqueous extracts of Gleichenia pectinata (Willd.) Ching. Circles represent replication values and the bars are the average values of treatments. When there is no overlapping of standard error ${ }^{\star} 1,5$, observed differences were considered significant.

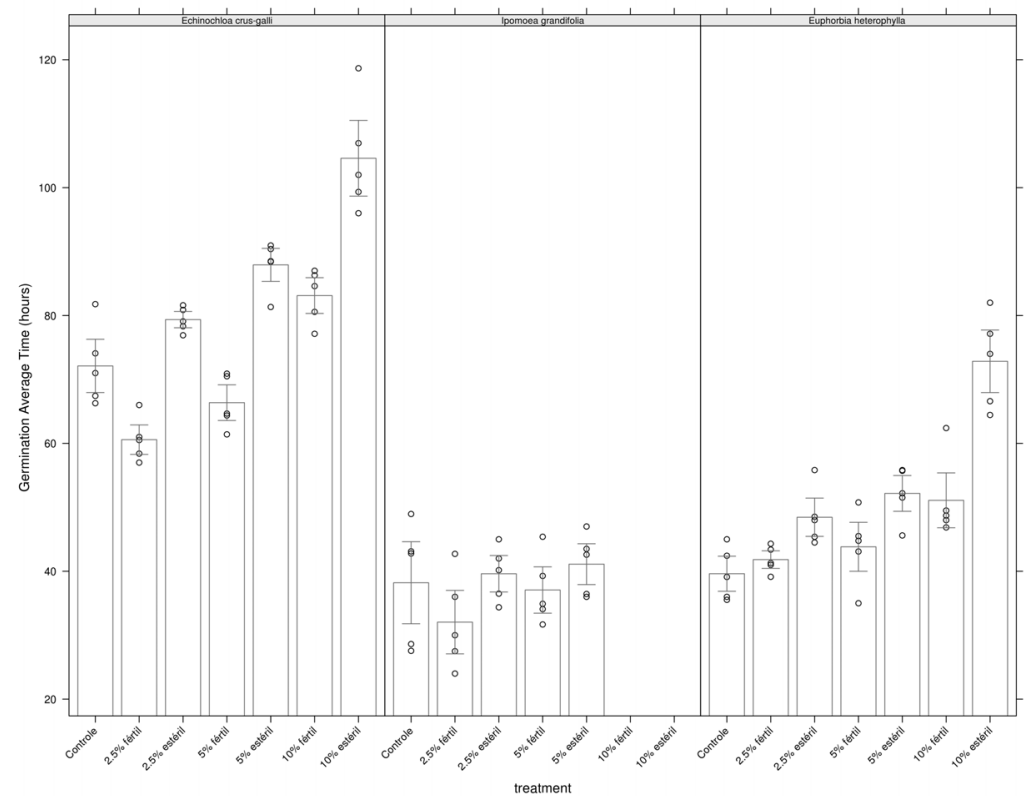

Figure 2. Average germination time of Echinochloa crus-galli (L.) Beauv, Ipomoea grandifolia (Dammer) O'Donell and Euphorbia heterophylla L. seeds when submitted to the aqueous extracts of Gleichenia pectinata (Willd.) Ching. Circles represent replications values and the bars are the average values of treatments. When there is no overlapping of standard error ${ }^{\star} 1,5$, observed differences were considered significant. 


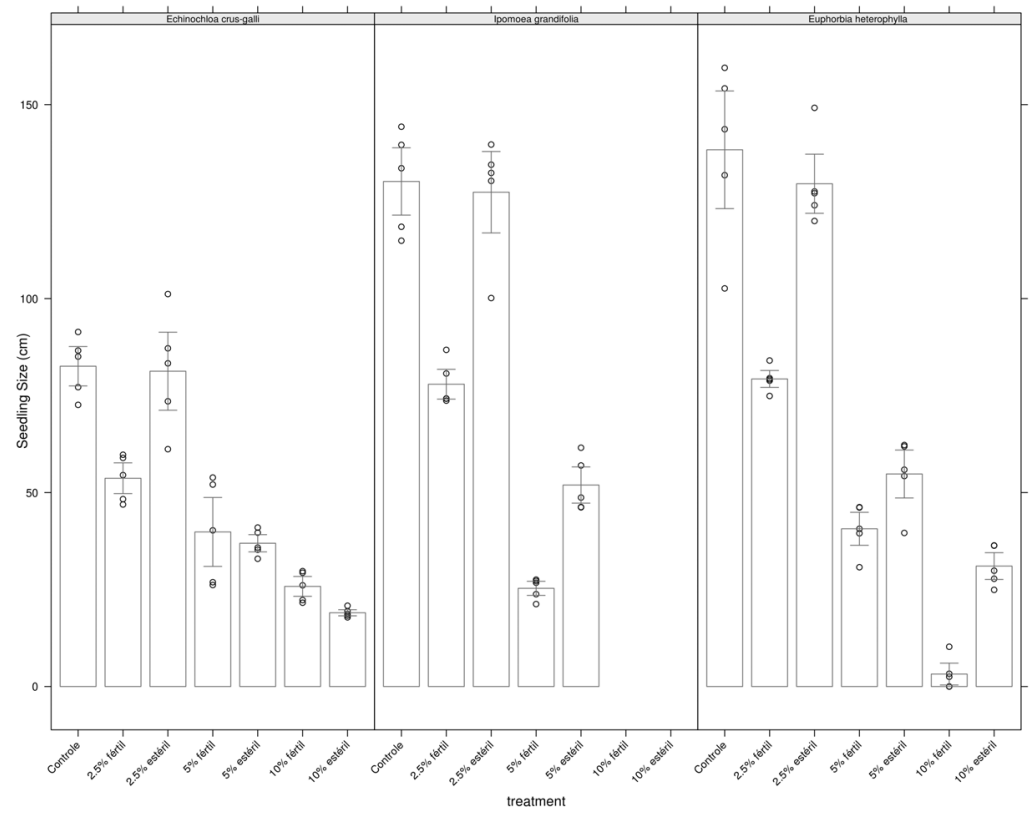

Figure 3. Average length of Echinochloa crus-galli (L.) Beauv, Ipomoea grandifolia (Dammer) O’Donell and Euphorbia heterophylla L. seedlings when submitted to the aqueous extracts of Gleichenia pectinata (Willd.) Ching. Circles represent replication values and the bars are the average values of treatments. When there is no overlapping of standard error ${ }^{\star} 1,5$, observed differences were considered as significant.

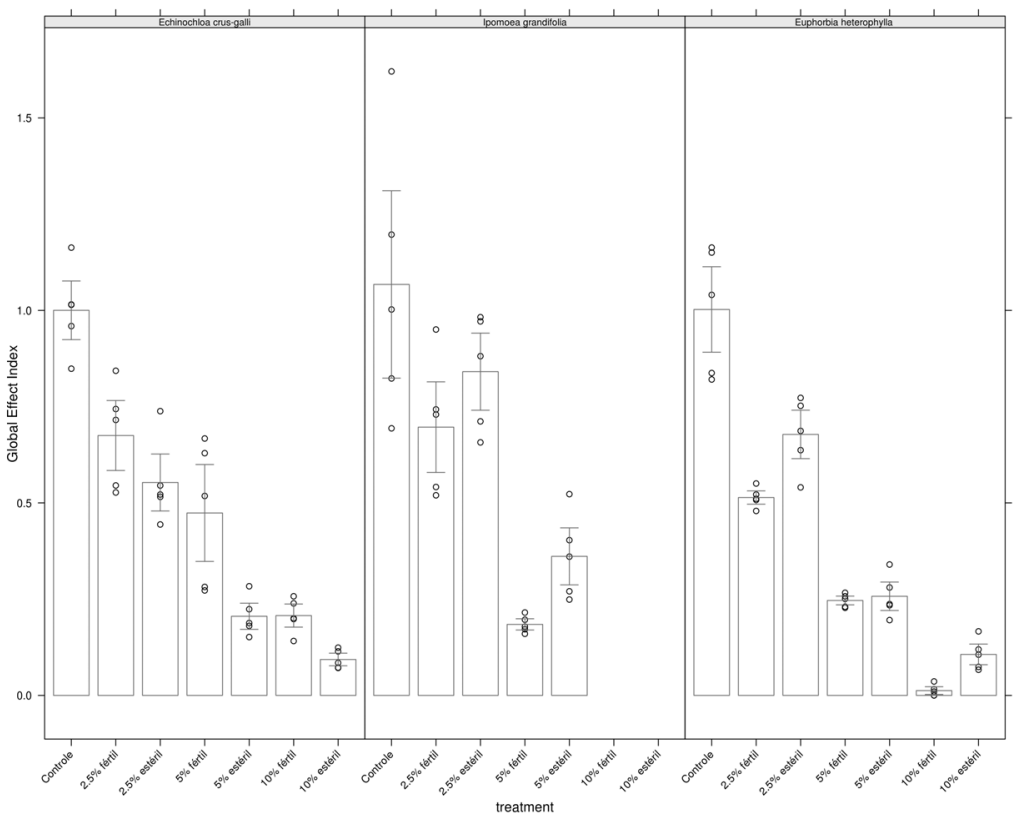

Figure 4. Global Index Effect Values of Echinochloa crus-galli (L.) Beauv, Ipomoea grandifolia (Dammer) O'Donell and Euphorbia heterophylla L. when submitted to the aqueous extracts of Gleichenia pectinata (Willd.) Ching. Circles represent replications values and the bars are the average values of treatments. When there is no overlapping of standard error ${ }^{\star} 1,5$, observed differences were considered as significant.

All target species were inhibited by all the treatments but the SF $2.5 \%$ on E. heterophylla (figure 2). Banding values together into a single value also helped to enhance differences between extracts FF and SF. Echinochloa crus-galli was more affected by the SF extracts whereas I. grandifolia and E. heterophylla were more sensitive to the FF extracts.
A qualitative analysis showed that exposing the seedlings to extracts, especially the most concentrated, lead to malformations, mainly gravitropism inversion and necrosis of the root apex. These responses are consistent with those found by other Pteridaceae researchers (Peres et al. 2004; Moraes and Garcia 2007). 

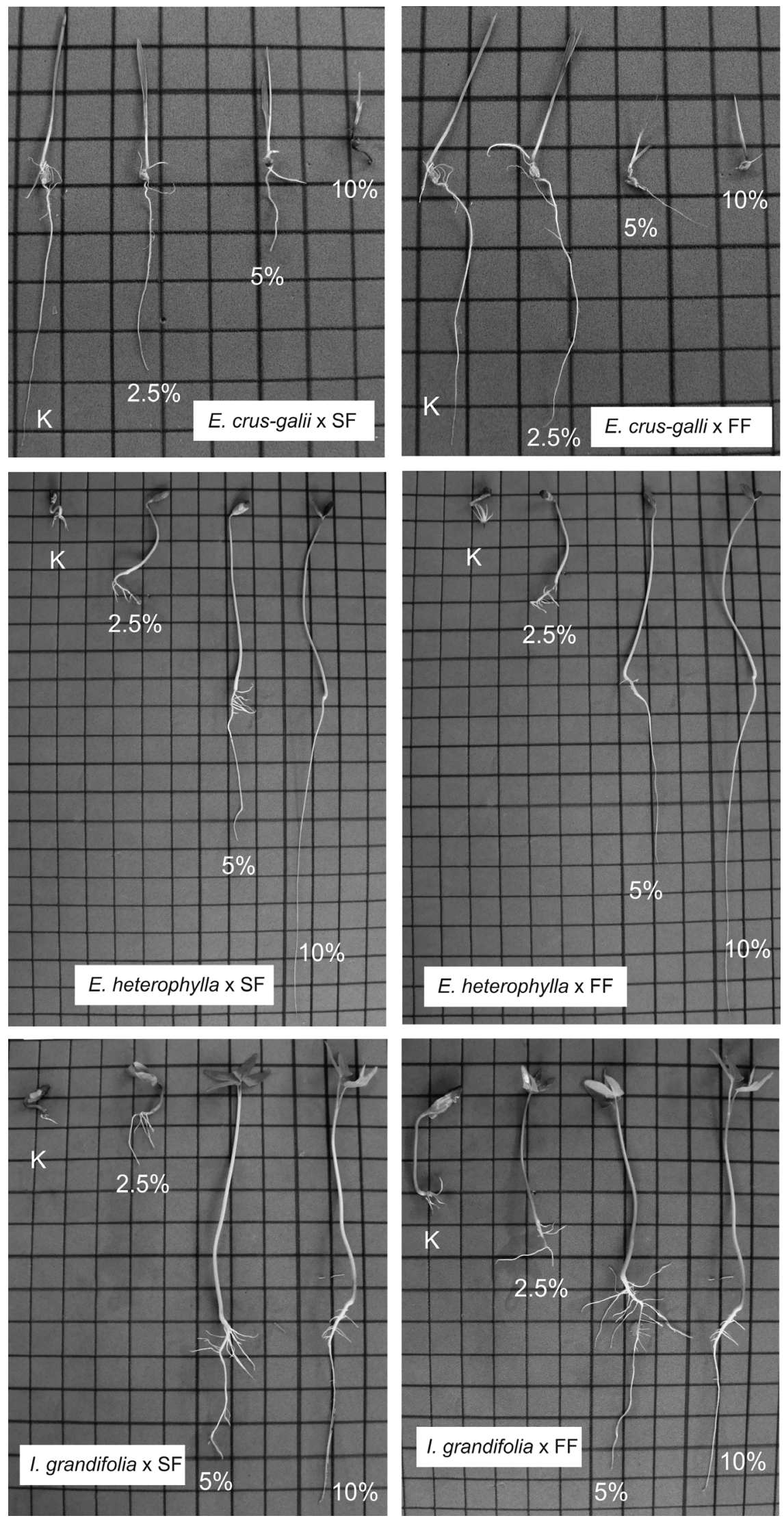

Figure 5. Anomalies of Echinochloa crus-galli (L.) Beauv, Ipomoea grandifolia (Dammer) O’Donell and Euphorbia heterophylla L. seedlings verified when submitted to the aqueous extracts of Gleicheniella pectinata (Willd.) Ching. Grid interval $=1 \mathrm{~cm}$. 
In studies related to the inhibitory effects of $G$. pectinata extracts, it was found that aqueous extracts caused chromosomal alterations and changed the development of lettuce seedlings (Lactuca sativa L.) and corn (Zea mays) (Campos et al. 2008). Gleicheniella pectinata extracts prepared with ethanol decreased the values of seed germination and onion (Allium cepa L.) seedling root length (Müller et al. 2007). The present study detected inhibitory properties of extracts, supporting the results of previous studies. Thus, despite the fact that further applied studies are required (Inderiit e Weston 2000), G. pectinata seems to be a viable donor plant to combat weed species. The alellopathic potential of this species could be explored as a way to control and manage weeds, as a replacement or in addition to synthetic herbicides.

\section{Acknowledgements}

To CNPq and CAPES for financial support, to the specialist Jefferson Prado for identification of the species, and to the technician team and workmates that contributed to this study.

\section{References}

Azania, A.A.P.M.; Azania, C.A.M.; Pavani, M.C.M.D. \& Cunha, M.C.S. 2003. Métodos de superação de dormência em sementes de Ipomoea e Merremia. Planta Daninha 21(2): 203-209.

Campos, J.M.S.; Davide, L.C.; Soares, G.L.G. \& Viccini, L.F. 2008. Mutagenic effects due to allelopathic action of fern (Gleicheniaceae) extracts. Allelopathy Journal 22(1): 143-152.

Christoffoleti, P.J.; Filho, R.V. \& Silva, C.B. 1994. Resistência de plantas daninhas aos herbicidas. Planta Daninha 12(1): 13-20.

Durán-Serantes, B.; González, L. \& Reigosa M.J. 2002. Comparative physiological effects of three allelochemicals and two herbicides on Dactylis glomerata. Acta Physiologiae Plantarum 24(4): 385-392.

FAO. Food and Agriculture Organization of the United Nations. http:// www.fao.org/news/story/en/item/29402/icode/. (Acesso em 18/11/2009).

Hong, N.H.; Xuan, T.D. \& Eiji, T. 2004. Paddy weed control by higherplants from Southeast Asia. Crop Protection 23(3): 255-261.
Inderjit \& Weston L.A. 2000. Are laboratory bioassays for allelopathy suitable for prediction of field responses? Journal of Chemical Ecology 26(9): 2111-2117.

Matsumoto, R.S.; Ribeiro J.P.N.; Takao, L.K. \& Lima, M.I.S. 2010. Potencial alelopático do extrato foliar de Annona Glabra L. (Annonaceae). Acta Botanica Brasilica 24(3): 631-635.

Moraes, L. \& Garcia, Q. 2007. Efeito alelopático de samambaia Sticherus lanuginosus (Feé) Nakai (Gleicheniaceae, Pteridophyta) sobre a germinação de sementes e crescimento inicial de alface. Revista Brasileira de Agroecologia 2(2): 970-973.

Müller, C.; Chagas F.F.; Peres, M.T.L.P.; Hess, S.C.; Faccenda, O. \& Daloso, D.M. 2007. Potencial Fitotóxico de Algumas Espécies de Gleicheniaceae sobre Allium cepa L.. Revista Brasileira de Biociências 5(2): 45-47.

Peres, M.T.L.P.; Pizzolatti, M.G.; Queiroz, M.H. \& Yunes, R.A. 1998. Potencial de Atividade Alelopática de Gleichenia pectinata Willd (PR.). Pesquisa Agropecuária Brasileira 33(2): 131-137.

Peres, M.T.L.P.; Silva, L.B.; Facenda, O. \& Hess, S.C. 2004. Potencial alelopático de espécies de Pteridaceae (Pteridophyta). Acta Botanica Brasilica 18(4): 723-730.

Reigosa, M.J.; González, L.; Sanches-Moreiras, A.; Duran, B.; Puime, D.; Fernandez, D.A. \& Bolana, J.C. 2001. Comparison of physiological effects of allelochemicals and commercial herbicides. Allelopathy Journal 8(2): 211-220.

Ribeiro, J.P.N. 2011. Global Effect Index: A new approach to analyzing allelopathy survey data. Weed Science Society of America 59(1): 113-118.

Ribeiro, J.P.N.; Matsumoto, R.S.; Takao, L.K. Voltarelli, V.M. \& Lima, M.I.S. 2009. Efeitos alelopáticos de extratos aquosos de Crinum americanum L. Revista Brasileira de Botânica 32(1): 183-188.

Rice, E.L. 1984. Allelopathy. New York, Academic Press.

SINDAG. Sindicato Nacional da Indústria de Produtos para Defesa Agrícola. http://www.sindag.com.br/. (Acesso em 17/11/2008).

Soares, G.L.G. \& Vieira, T.R. 2000. Inibição de germinação e do crescimento radicular de alface (CV. "grand Rapids") por extratos aquosos de cinco espécies de Gleicheniaceae. Floresta e Ambiente 7(1): 180-197.

Souza Filho, A.P.D.S.; Rodrigues, L.R.D.A. \& Rodrigues, T.J.D. 1996. Efeitos de extratos aquosos de assa-peixe sobre a germinação de três espécies de braquiária. Planta Daninha 14(2): 93-101.

Tranel, P.J. \& Wright, T.R. 2002. Resistance of weeds to ALS-inhibiting herbicides: what have we learned? Weed Science 50(6): 700-712.

Villela, F.A.; Filho, L.D. \& Sequeira, E.L. 1991. Tabela de Potencial Osmótico em Função da Concentração de Polietileno Glicol 6000 e da Temperatura. Pesquisa Agropecuária Brasileira 26(12): 1957-1968. 